TILTAI, 2021, 1, 168-185 ISSN 1392-3137 (Print), ISSN 2351-6569 (Online); DOI: 10.15181/tbb.v86i1.2266

\title{
THE MANAGEMENT OF A VIRTUAL PROJECT TEAM IN AN INTERNATIONAL COMPANY: THE PERSPECTIVE OF VIRTUAL PROJECT TEAM LEADERS
}

\author{
Aistė Kukytė, Edmundas Jasinskas \\ Vilnius University
}

\begin{abstract}
The article analyses the management of a virtual project team in international companies. It provides a theoretical overview of virtual project team management, and the results of the research are presented. A qualitative study was carried out in which a structured interview was used to interview managers working in international companies who lead virtual project teams. The study involved nine informants, working in Lithuania, the United Kingdom, the United States, Bangladesh, France, Malaysia and Poland. The results of the study revealed the influence of information and communication technologies in managing a virtual project team, how emotional and motivational processes are managed, the importance of trust to a virtual project team, and how team management is improving. To summarise the research, the results provide a virtual project team management model that benefits companies and virtual project team managers who strive for the productive management of these teams.

KEY WORDS: virtual project team, management of virtual project team, management in international companies.

Anotacija

Straipsnyje analizuojamas virtualios projekto komandos valdymo tarptautinėse įmonėse klausimas. Pateikiama teorinė apžvalga, kas būdinga virtualios projekto komandos valdymui, atlikto tyrimo rezultatai. Atliktas kokybinis tyrimas: struktūruotu interviu apklausti tarptautinėse įmonèse dirbantys vadovai, vadovaujantys virtualiai projekto komandai. Tyrime dalyvavo 9 Lietuvoje, Jungtineje Karalysteje, Jungtinėse Amerikos Valstijose, Bangladeše, Prancūzijoje, Malaizijoje ir Lenkijoje dirbantys informantai. Tyrimo rezultatai atskleidè informacinių ir ryšių technologijų poveikị virtualios projekto komandos valdymo procesui: kaip valdomi emociniai ir motyvaciniai procesai, kuo virtualiai projekto komandai svarbus pasitikejimas, kaip tobulinamas komandos valdymas. Apibendrinus apklausos rezultatus pateikiamas virtualios projekto komandos valdymo modelis, kuris gali būti naudingas įmonėms, virtualių projektų komandų vadovams, siekiantiems veiksmingai valdyti komandas.

PAGRINDINIAI ŽODŽIAI: virtuali projekto komanda, virtualios projekto komandos valdymas, tarptautinių įmonių valdymas.
\end{abstract}

DOI: http://dx.doi.org/10.15181/tbb.v86i1.2266

\section{Introduction}

Effective organisational management is the most direct path to success. Traditional management methods are not enough for a competitive organisation in the current context of globalisation. This is the same in the context of international business. Organisations are increasingly using virtual project teams to take advantage of globalisation and multiculturalism. With advantages such as diverse team 
members, wide organisational boundaries, a flexible organisational structure and the allocation of innovation resources, the virtual team has been widely accepted in many areas, including services, information technology, and innovation, research and development (Bhat et al., 2017). These teams can take a variety of forms, from a team that works regularly with a specific project built on a specific project, to teams whose members are spread out around the world (Eubanks et al., 2016).

The research literature uses terms for these teams, such as 'global team', 'virtual team' and 'virtual project team'. According to Maloney and Zellmer-Bruhn (2006), global teams typically dictate both diverse memberships and locations scattered around the world; in addition, members represent different parts of an international organisation, may come from different countries and cultures, and may represent different business functions. According to Wadsworth and Blanchard (2015), virtual teams exist in a continuum, where some teams are completely virtual and never reach traditional face-to-face communication, and others are somewhat virtual, where team members first interact in the traditional face-to-face way, but also spend time working with each other through information and communication technologies. Because virtual teams break down barriers of time and space, they can also make the most of the experience of the members of an organisation; therefore, given these characteristics, virtual teams have a huge potential to improve organisational efficiency (Duran, Popescu, 2014). The authors Bahat et al. (2017) describe the virtual team as a team composed of employees of different genders, backgrounds, environments and geographical areas, whose members rely mainly or exclusively on the use of information and communication technologies for their common goals. The virtual project team has the same features as the virtual team, but it is also temporary, as the team is assembled for a certain period of time to complete a project (Zuofa, Ochieng, 2017).

Looking at the opinion of Gibbs et al. (2017) of virtual project team management, it is necessary for the team leader to establish the structure, to define more clearly the common goals and vision, and to coordinate tasks in the virtual team. According to Browne et al. (2016), in international projects where resources and project team members are located around the world, it is worth considering the various risks, the impact on quality, and what the key success factors in global team management are. Hertel et al. (2005) singled out principles that should be applied in the management of virtual teams. The authors single out more general principles of virtual team management (Hertel et al., 2005) that a team needs: clear goals and team roles that do not conflict with other units at work; to thoroughly implement effective communication and cooperation processes to prevent misunderstandings and escalation of conflict due to reduced aspects of communication; constant team awareness support, informal communication and sharing of social 
and emotional cues, as well as sufficient feedback and information on the individual work situation of each virtual team member; experience of interdependence within the team must be developed to compensate for feelings of relaxation, for example, through goal setting, task creation or team incentives; to develop appropriate workshops and team training concepts to prepare and support teams for specific virtual teamwork challenges.

Due to the largely dispersed nature of virtual project teams, virtual team management poses several challenges. As there is very little face-to-face communication, there is a lack of communication, coordination and trust, there is a lack of clarity about the roles of each member, and there are misunderstandings about the purpose of the larger project (Mukherjee, Natrajan, 2017). Thus, the presence of such teams in the activities of organisations poses additional challenges for international business. In this context, the research questions arose: How to properly manage virtual project teams? How do information and communication technologies influence virtual team management? How are motivational and emotional processes managed in a virtual project team in international companies? What are the traits of virtual project team leadership? How can virtual project team management techniques be improved? What is the importance of trust in virtual project team management?

The object of the research is the management of a virtual project team in an international company.

The aim of the research is to investigate the features of virtual project team management in international companies from the point of view of virtual project team leaders.

Research methods: the qualitative research method was used to gather the necessary information. Classification and systematisation were chosen for data processing.

\section{Methods of Research}

\subsection{Study design and setting}

The study was conducted in 2019 and 2020. Following a review of the literature, and based on the ideas of researchers who analysed virtual teams, virtual project teams and their management components from various perspectives, structured interview questions were prepared. Due to the participation in the study of foreign informants, the interviews were conducted in Lithuanian and English. The main questions in the structured interview were based on an analysis of theoretical and empirical research, thus the following questions were formulated: How do in- 
formation and communications technologies help to manage a virtual team? Does the advancement of technology change the methods used in your management? If so, how do you change them? Can you give examples? How do you manage the motivational and emotional processes of a virtual team, like training, conflict management, creating a safe climate, increasing team cohesion, etc? Can you give examples? What is typical of you as a virtual team manager (features, policies, etc)? Do you as a manager agree that you are a team leader? Are there emerging leaders in your team without you, and how do you allow them to emerge? Are you improving virtual team management techniques during team management, and how do you improve them? What value to a team does trust in each other give? What might happen in the team if there was none? Can trust solve emerging management problems? What more can you say about the virtual team you manage and your management?

Interviews were conducted by interviewing informants orally or in writing. The basic principles of research ethics were followed: fairness (respect for privacy, questioning honestly and confidentially), respect and goodwill. To determine the sample of the study, a selection of criteria was chosen: people interviewed who work in international companies and lead virtual project teams that operate virtually and whose members are geographically dispersed were selected. The study was conducted based on qualitative data analysis, which results in the categorisation and coding of data for all data collection periods. Categories were then defined and interrelated with other categories. Classification and systematisation were chosen for data processing. To obtain data, classify and systematise, each informant was given a unique informant code, reflecting the gender of the informant and the country in which he/she works, based on the ISO 3166 geographical coding standard. This article presents only part of the most important research results.

Informants were sought through the LinkedIn network. The search was performed under the job titles 'global team manager', 'virtual team manager' and 'global team leader'. Each person was contacted personally by introducing the purpose of the study and stating what kind of informants were sought. Interviews were further discussed with the individuals. The conversations were conducted using Messenger, Skype and Google meet programs. Two participants in the study did not agree to be interviewed through the above-mentioned programs, and at their request the interview was conducted by correspondence. Nine people participated in the study, the data saturation was visible by interviewing the last two informants; therefore, it can be stated that the number of respondents is appropriate. To maintain the anonymity of informants in this study, each informant was given a unique code reflecting the informant's gender (female [M], male [V]) and the country in which he or she works according to the ISO 3166 geocoding standard, which encodes country and 
Aistė Kukytè, Edmundas Jasinskas

dependent territory names (United Kingdom [GB], United States [US], Bangladesh [BD], France [FR], Malaysia [MY], Poland [PL], Lithuania [LT]).

\section{Results}

\subsection{Participants}

Nine informants participated in the study. The first is a woman living in the United States. She has been leading virtual teams since 2007, and has been leading the current managed team in an international company since 2011. The team led consists of six full-time team members and two part-time team members. The team members were scattered around the United States and India. The team consists of four men and two women. Informant code M-US.

The second informant, a man working in the United Kingdom, is Lithuanian, and has led virtual teams for two years. The teams are diverse and multiple at a time, depending on the tasks. A team usually consists of three or five people. Employees are scattered throughout Lithuania, Germany, Portugal, Moldova, and other countries. About $80 \%$ of individuals are men. Informant code V-GB.

The third informant is a man working in Bangladesh, who has led virtual teams for two and a half years. The current team consists of 36 individuals, scattered throughout Britain, Bangladesh, Kuwait, Saudi Arabia and Oman. They include 30 men and six women. Informant code V-BD.

The fourth informant is a Lithuanian woman working in France, who has led virtual teams for three years, the current team for six months. The number of team members depends on the project. Team members are from all over the world: Argentina, the USA, India, France and South Africa; and the distribution of members by gender varies. Informant code M-FR.

The fifth informant is a Lithuanian woman working in Malaysia, who has experience of leading virtual teams for about a year and a half. The current managed team consists of about 40 individuals. The team members are from Estonia, France, Costa Rica, Lebanon, Egypt, Germany, Brazil, and the Philippines. The team consists of about $70 \%$ women and $30 \%$ men. Informant code M-MY.

The sixth informant is a man from Poland with leadership experience of virtual teams of more than five years, who has been leading the current team for three months. The team consists of ten people, from Poland, Spain and the Netherlands. There are seven women and three men on the team. Informant code V-PL.

The seventh informant is a woman working in Lithuania, with leadership experience of a virtual team of about six months. The team consists of people from 
three cultures, from England, Germany and Sweden, all women. Informant code M-LT.

The eighth informant is a man working in Lithuania, with leadership experience of virtual teams of more than five years. He has been leading the current team for over a year. The team consists of 20 people, from Lithuania, Poland, Estonia and Latvia. The team consists of $80 \%$ women and $20 \%$ men. Informant code V-LT.

The ninth informant is a woman working in Denmark, with virtual team leadership experience of nearly a year, as well as time leading the current team. The team consists of three women and one man, from Lithuania and India. Informant code M-DK.

\subsection{The main results}

The first questions asked in the interview were about the experience of leading a virtual project team, in order to understand the informants' experience, and to find out if the informant fits the criteria for an informant. Then specific questions were asked. Informants were asked open-ended questions to find out the impact of information and communication technologies on virtual project team management. Table 1 distinguishes the category according to the answers provided 'The influence of information and communication technologies on virtual project team management', and four subcategories describing the opinions of informants about the influence of information and communication technologies.

Based on the results in Table 1, it can be stated that information and communication technology is the main tool to help manage virtual teams in international companies. As the technology itself evolves, management tools and methods are also being refined. As informant V-GB states, '(...) the whole platform it is improved every month, there are three constant programmers, as an example we say we send them messages like "Hello I would be good for such a task if the system should that and that." We see for ourselves that we are missing, please do.' Improvements are ongoing to provide additional functionality to keep pace with the market. Technological advancements help more effective management to take effect in virtual teams, not only at the overall team level but also in person, as it enables members to act more independently. It should be noted that at the overall team level, technology facilitates not only cooperation between members, but also the quick resolution of problems. 
Aistė Kukytè, Edmundas Jasinskas

Table 1. The influence of information and communication technologies on virtual project team management

\begin{tabular}{|c|c|c|}
\hline Category & Subcategory & Confirming statements by informants \\
\hline \multirow[t]{4}{*}{$\begin{array}{l}\text { The influ- } \\
\text { ence of in- } \\
\text { formation } \\
\text { and com- } \\
\text { munication } \\
\text { technolo- } \\
\text { gies on vir- } \\
\text { tual project } \\
\text { team man- } \\
\text { agement }\end{array}$} & $\begin{array}{l}\text { Continuous } \\
\text { improvement }\end{array}$ & $\begin{array}{l}\text { 'As technology changes, so do the tools we use (...)' (M- } \\
\text { US) } \\
\text { '(...) my management improves with the development } \\
\text { of technologies such as it was previously only in those } \\
\text { google hangouts but later we saw that Zoom can be used } \\
\text { (...)' (M-MY) } \\
\text { 'Automation of processes is gradually adapted to certain } \\
\text { processes, which simplifies the work and saves time' (M- } \\
\text { DK) }\end{array}$ \\
\hline & $\begin{array}{l}\text { Enables mem- } \\
\text { bers to act } \\
\text { independently }\end{array}$ & $\begin{array}{l}\text { 'The better the tools get the easier it is manage and allow } \\
\text { the team members to be more empowered to work on their } \\
\text { own and make their own decisions' (M-US) }\end{array}$ \\
\hline & $\begin{array}{l}\text { Supporting } \\
\text { team mem- } \\
\text { bers' collabo- } \\
\text { ration }\end{array}$ & $\begin{array}{l}\text { 'The tools make it easier for team members to collaborate } \\
\text { without one person being responsible for an entire task or } \\
\text { process' (M-US) }\end{array}$ \\
\hline & $\begin{array}{l}\text { Helps solve } \\
\text { problems }\end{array}$ & $\begin{array}{l}\text { 'It helps a lot to solve problems quickly, make calls or } \\
\text { communicate immediately via Skype. No need for live } \\
\text { meetings' (M-FR) } \\
\text { '(...) as many different platforms as possible where we can } \\
\text { not only correspond but also talk or call then it is much } \\
\text { easier because certain challenges can be solved and even } \\
\text { things like voice messages can be very helpful and act as } \\
\text { an intermediate option between correspondence or calls } \\
\text { (...)' (M-MY) }\end{array}$ \\
\hline
\end{tabular}

Another question 'How do you manage the motivational and emotional processes of a virtual team, like training, conflict management, creating a safe climate, increasing team cohesion, etc? Can you give examples?' was asked to find out how managers manage the motivational and emotional processes of a virtual project team. Table 2 presents the category 'Management of motivational and emotional processes of a virtual project team', and six subcategories as confirmatory statements by the informants. 
THE MANAGEMENT OF A VIRTUAL PROJECT TEAM IN AN INTERNATIONAL...

Table 2. Management of motivational and emotional processes of a virtual project team

\begin{tabular}{|c|c|c|}
\hline $\begin{array}{l}\text { Cat- } \\
\text { egory }\end{array}$ & Subcategory & Confirming statements by informants \\
\hline \multirow{6}{*}{$\begin{array}{l}\text { Man- } \\
\text { agement } \\
\text { of moti- } \\
\text { vational } \\
\text { and } \\
\text { emo- } \\
\text { tional } \\
\text { process- } \\
\text { es of a } \\
\text { virtual } \\
\text { project } \\
\text { team }\end{array}$} & $\begin{array}{l}\text { Training } \\
\text { (group, indi- } \\
\text { vidual, in-team } \\
\text { learning) }\end{array}$ & $\begin{array}{l}\text { '(...) team members themselves know what their strengths } \\
\text { are in teaching others and the goal that it comes not only } \\
\text { from the manager or from some official people but also from } \\
\text { the people themselves they are encouraged to reveal their } \\
\text { strengths' (M-MY) } \\
\text { 'When it comes to informal training, I find that the team does } \\
\text { a great job of that on their own. In some cases when a team } \\
\text { member learns how to do something, they will take it upon } \\
\text { themselves to share it with the entire team' (M-US) }\end{array}$ \\
\hline & $\begin{array}{l}\text { Conflict man- } \\
\text { agement }\end{array}$ & $\begin{array}{l}\text { 'In a conflict situation, I try to find out the cause and make } \\
\text { suggestions on how to resolve the situation' (M-FR) } \\
\text { 'Making video calls, seeing human reactions, solving conflict } \\
\text { situations, solving problems' (M-LT) } \\
\text { '(..) due to conflicts or some kind of challenge, emotional } \\
\text { things, it is clear that everything is talked during personal } \\
\text { conversations and then there is watching what is happening } \\
\text { and how it is happening' (M-MY) }\end{array}$ \\
\hline & $\begin{array}{l}\text { Reduction of } \\
\text { personal inter- } \\
\text { action }\end{array}$ & $\begin{array}{l}\text { 'Since there is less personal interaction, there is lesson ten- } \\
\text { sion and much fewer issues of people taking things person- } \\
\text { ally' (M-US) } \\
\text { 'I talk to people in the work environment, or I only discuss } \\
\text { work, and if there are problems, they arise at work, no other } \\
\text { contradictions or personal such things happen there' (V-GB) }\end{array}$ \\
\hline & $\begin{array}{l}\text { Creating a } \\
\text { secure climate } \\
\text { through com- } \\
\text { pany policies } \\
\text { and rules }\end{array}$ & $\begin{array}{l}\text { 'I think our company culture has focused on a safe climate. } \\
\text { We are taught every year what is and what is not safe' (M- } \\
\mathrm{US}) \\
\text { 'In fact, we have such a policy in the company, i.e. several } \\
\text { basic rules are very clearly defined (...) we never talk about } \\
\text { politics, we never talk about religion let's call it non-debate } \\
\text { and we all speak the same language (...)' (V-GB) }\end{array}$ \\
\hline & $\begin{array}{l}\text { Ensuring team } \\
\text { coherence }\end{array}$ & $\begin{array}{l}\text { 'I personally encourage all team members to turn on the ca- } \\
\text { meras so we can see each other, and that helps a lot' (V-PL) } \\
\text { 'It is important to maintain a friendly but sufficiently profes- } \\
\text { sional relationship' (M-DK) }\end{array}$ \\
\hline & Motivation & $\begin{array}{l}\text { 'I always try to motivate and praise team members for their } \\
\text { efforts' (M-FR) } \\
\text { 'Team microclimate is very important to maintain employee } \\
\text { motivation, well-being at work' (M-DK) }\end{array}$ \\
\hline
\end{tabular}

Assessing how team leaders manage the motivational and emotional process, it is possible to distinguish the main tools as it is done in virtual teams (Table 2). 
Aistė Kukytè, Edmundas Jasinskas

Training can be formalised according to the needs of the team members or the individual member at the discretion of the manager ("We discuss what training we think is needed and help each other find available training within our internal system or externally,' M-US). Informally, the team learns internally among its members, sharing experience from formal training, or teaching each other how to perform certain tasks. It should be noted that the motivational and emotional processes of team members are managed through information and communication technologies ('We attend group meetings on skype, have an online chat. We also observe teamwork through DeskTime software,' V-BD). Conflicts in virtual teams are managed more easily than in traditional teams, as informant M-US says. Conflict management in virtual teams is much easier due to less personal interaction. Managers solve problems and conflicts depending on the situation in the team openly or individually. Existing policies and regulations within companies help to foster a safe climate, reduce the occurrence of problems, and thus contribute to the management of motivational and emotional processes. Team coherence is also affected by a safe climate among team members. Managers maintain coherence in teams by motivating individual conversations and praise and paying attention to each team member. As informant M-MY puts it: '(...) it's especially important to let people know that they notice them in a good way (...) every week every two or two sentences of my mini-message completely changed their mood, it's just to support that kind of motivation in nice words and notice what people do doing well is especially important.'

The following questions were designed to understand the signs of virtual project team leadership. Table 3 presents the category 'Virtual project team leadership traits' and eight subcategories with informant affirmative statements.

In summary, virtual team leadership is characterised by the equivalence of work that is always ensured. Team leaders seek to maintain honesty with team members, adherence to deadlines, spreading motivation, and emerging leadership empowerment. 'I lead my team with great motivation and hope to become leaders rather than followers,' V-BD said. Leadership in virtual teams is characterised by empathy, brainstorming, help and support. Managers try to follow the company's policy and established rules by setting clear goals and rules for team members. Emerging leadership in virtual teams is dominated by the level of maturity of the members, the environments created to enable them, their professional experience, the opportunity to develop their abilities and leadership, and to take on more responsibilities.

Informants were asked 'Are you improving virtual team management techniques during team management and how do you improve them?' to understand how the management of the virtual project team is or is being improved. Informants' responses are presented in Table 4. 
Table 3. Virtual project team leadership traits

\begin{tabular}{|c|c|c|}
\hline Category & Subcategory & Confirming statements by informants \\
\hline \multirow[t]{3}{*}{$\begin{array}{l}\text { Virtual } \\
\text { project team } \\
\text { leadership } \\
\text { traits }\end{array}$} & $\begin{array}{l}\text { Maintaining } \\
\text { personal life } \\
\text { and work bal- } \\
\text { ance }\end{array}$ & $\begin{array}{l}\text { 'Since we are all working together all the time, it is } \\
\text { easier to hand off from one person to another and sup- } \\
\text { port work-life balance' (M-US) } \\
\text { 'But because we are a team, we try to reallocate jobs so } \\
\text { that there is no risk of burn-out' (M-LT) }\end{array}$ \\
\hline & $\begin{array}{l}\text { Equivalent } \\
\text { work }\end{array}$ & $\begin{array}{l}\text { 'I put myself out there as much as anyone' (M-US) } \\
\text { 'I am such a manager who is also a member of the team } \\
\text { and together with the whole team we are looking for the } \\
\text { best ways to perform tasks together and on time' (V-LT) }\end{array}$ \\
\hline & $\begin{array}{l}\text { Maintaining } \\
\text { constant com- } \\
\text { munication }\end{array}$ & $\begin{array}{l}\text { 'I facilitate communication between team and across the } \\
\text { organisation' (M-US) } \\
\text { 'Every weekly meetings via Zoom, constant communica- } \\
\text { tion via skype, emails' (M-LT) } \\
\text { 'I constantly see how my team works, so I can steer } \\
\text { them in the right direction, advise, if necessary, ask for } \\
\text { more effort and so on' (M-LT) }\end{array}$ \\
\hline & $\begin{array}{l}\text { Promoting } \\
\text { cooperation }\end{array}$ & $\begin{array}{l}\text { 'I promote a positive environment where everyone } \\
\text { supports everyone else' (M-US) }\end{array}$ \\
\hline & $\begin{array}{l}\text { Goal setting } \\
\text { and mainte- } \\
\text { nance }\end{array}$ & $\begin{array}{l}\text { 'My team has a structure that I established and there } \\
\text { are no issues with sustaining it' (V-PL) } \\
\text { 'It is very important to have preconceptions about how } \\
\text { we communicate virtually and how tasks are delegated } \\
\text { (...)' (V-LT) } \\
\text { 'Pre-defined general rules, the clearest possible commu- } \\
\text { nication by letters and the organisation of video confe- } \\
\text { rences (...) important detailed descriptions of processes } \\
\text { and their updates' (M-DK) }\end{array}$ \\
\hline & $\begin{array}{l}\text { Disclosure of } \\
\text { qualities to } \\
\text { team members }\end{array}$ & $\begin{array}{l}\text { 'Honest, see deadlines, clearly delegate tasks' (V-GB) } \\
\text { 'Empathy, listening to team member suggestions, team } \\
\text { support and support help maintain a strong team spirit' } \\
\text { (M-FR) }\end{array}$ \\
\hline
\end{tabular}


Aistė Kukytè, Edmundas Jasinskas

\begin{tabular}{|l|l|l|}
\hline Category & Subcategory & Confirming statements by informants \\
\hline & Fostering & 'I lead my team with great motivation and hope they \\
emerging & become leaders, not followers' (V-BD) \\
leadership & 'If anyone succeeds, I really don't interfere, I just praise \\
and let it unfold' (M-LT) \\
'(...) I would say how certain projects or challenges are, \\
for example, and how people express their opinions, \\
offer solutions we sometimes form as I say those wor- \\
king groups where it is certain people who take initiati- \\
ves' (M-MY)
\end{tabular}

Summarising the informants' opinions on ways to improve the management of virtual teams (Table 4), we can state that the improvement process takes place by observing the market, and communicating with professionals in the field. The team itself can encourage the improvement of the methods used by the manager by changing their goals. It should be noted that team management improves with experience, lessons are learned, but it is also possible that in some cases improvement processes do not take place due to the lack of time: 'Usually there is no time for this due to the heavy workload,' M-FR said.

Another important aspect for which clarification was sought in the study is the importance of trust in the virtual project team. The opinion of informants is presented in Table 5 in the category 'The importance of trust in the virtual project team', which distinguishes three subcategories. 
Table 4. Improvement of virtual project team management

\begin{tabular}{|c|c|c|}
\hline Category & Subcategory & Confirming statements by informants \\
\hline \multirow[t]{4}{*}{$\begin{array}{l}\text { Improvement } \\
\text { of virtual } \\
\text { project team } \\
\text { management }\end{array}$} & $\begin{array}{l}\text { Market monitor- } \\
\text { ing }\end{array}$ & $\begin{array}{l}\text { '(...) we are not lagging behind what is happening in } \\
\text { the market, we also look at what we are missing and } \\
\text { how to improve ourselves from it' (V-GB) } \\
\text { '(...) our management regularly organises distance } \\
\text { learning' (M-LT) }\end{array}$ \\
\hline & $\begin{array}{l}\text { Communication } \\
\text { with profession- } \\
\text { als in the field }\end{array}$ & $\begin{array}{l}\text { 'I am active on LinkedIn and network with other } \\
\text { virtual team managers and community professionals' } \\
\text { (M-US) }\end{array}$ \\
\hline & Team influence & $\begin{array}{l}\text { '(...) I think the team dictates how I change. As they } \\
\text { change or their goals change I need to adjust' (M- } \\
\text { US) } \\
\text { '(...) I really like even the teams to ask what's still } \\
\text { working and what's not and how we can turn it } \\
\text { around' (M-MY) } \\
\text { 'More often regular feedback sessions and perfor- } \\
\text { mance monitoring helps a lot' (V-PL) }\end{array}$ \\
\hline & $\begin{array}{l}\text { Influence of } \\
\text { professional } \\
\text { experience and } \\
\text { work lessons }\end{array}$ & $\begin{array}{l}\text { 'We watch all the time, or say every project or task } \\
\text { still brings new knowledge, experience and eve- } \\
\text { rything else (...) two years ago as we started using } \\
\text { our platform it was like in the initial beta version } \\
\text { (...) in the past there let's call it open task and put } \\
\text { together fifteen people we realized all this is no } \\
\text { longer needed, we need to keep as little as possible in } \\
\text { people's tasks' (V-GB) }\end{array}$ \\
\hline
\end{tabular}

Summarising the opinions of informants, trust is of great importance in the work of virtual project teams. As informant V-LT states: 'Trust is one of the most important things, without trust we do not go anywhere.' Trust helps the team to achieve results, and strengthens teamwork, which depends on the level of trust. It is the presence of trust that can help prevent conflicts emerging, and reduce the occurrence of problems. It is important to mention that trust not only strengthens teamwork, but also improves productivity: 'A team would work, share work and perform it successfully only with the trust of each team member and knowing that he would do the assigned work properly,' M-DK said. 
Aistė Kukytè, Edmundas Jasinskas

Table 5. The importance of trust in virtual project team management

\begin{tabular}{|c|c|c|}
\hline Category & Subcategory & Confirming statements by informants \\
\hline \multirow[t]{3}{*}{$\begin{array}{l}\text { The im- } \\
\text { portance } \\
\text { of trust in } \\
\text { a virtual } \\
\text { project } \\
\text { team man- } \\
\text { agement }\end{array}$} & Teamwork & $\begin{array}{l}\text { 'There can be no teamwork without trust' (M-FR) } \\
\text { 'We trust each other to do what we say we will do, and our } \\
\text { work depends on it' (M-US) } \\
\text { 'We need to trust team members and not judge them by } \\
\text { mistake, but make a suggestion on how to do better next } \\
\text { time' (M-FR) }\end{array}$ \\
\hline & $\begin{array}{l}\text { Stopping the } \\
\text { rise of prob- } \\
\text { lems }\end{array}$ & $\begin{array}{l}\text { '(...) trust helps prevent conflicts and facilitates my work } \\
\text { as a leader. By trusting team members, we work better to- } \\
\text { gether and are prepared to solve problems together without } \\
\text { my involvement' (M-US) } \\
\text { 'If the task of trust had not been fulfilled or if it had been } \\
\text { performed very poorly, or if there had been some conflicts, } \\
\text { redundancies, chaos' (V-GB) } \\
\text { '(...) I think that trust is the basis of everything and if it is } \\
\text { not there then everything that is worst happens (...)' (M- } \\
\text { MY) }\end{array}$ \\
\hline & $\begin{array}{l}\text { Enhances } \\
\text { productivity }\end{array}$ & $\begin{array}{l}\text { 'Lack of trust will lead to less productive work' (V-BD) } \\
\text { 'Project management means constant communication with } \\
\text { people, trust in them, without it, there are problems that } \\
\text { immediately respond to the project itself and customer } \\
\text { satisfaction with the service' (M-LT) } \\
\text { 'I think trust in each other is one of the essential features } \\
\text { needed for a successful team mechanism, it would have a } \\
\text { huge impact on the quality of work' (M-DK) }\end{array}$ \\
\hline
\end{tabular}

\subsection{Virtual project team management model} in international companies

Based on the results of the study conducted, a virtual project team management model in international companies has been prepared. Based on the results of the study, from the point of view of virtual project team leaders in international companies, the existing virtual project team management aspect was revealed. The model is useful for companies that seek to properly manage virtual project teams, as well as for productive teamwork. In the model (Fig. 1), relationships and influence are indicated by arrows; the whole control process is cyclical. The connections depicted by dotted lines show that the processes do not take place continuously.

In the model, teams are managed through information and communication technology, leadership, and the management of motivational and emotional processes (Fig. 1). Information and communication technologies provide uninterrupted communication, work platforms and personal communication with each team 
member, and enable members to act independently, support team collaboration and help solve problems. The aim is for the ongoing communication process to support effective collaboration through the clear communication of information and requirements. Because the virtual team is supported by technologies that ensure that members can always be connected, the goal is to ensure that communication is ensured at all times, and that participants can communicate regardless of their geographical location. It should be noted that at the overall team level, technology facilitates not only cooperation between members, but also the quick resolution of problems.

Leadership in virtual teams is characterised by equal work, which should always be ensured. Team leaders should maintain honesty with team members, meeting deadlines, spreading motivation, and empowering emerging leaders. Leadership in virtual project teams should be characterised by empathy, brainstorming, help and support. Managers should support company policies and established rules, by defining clear goals and rules for team members. Live meetings are also important in managerial leadership, which in some cases is necessary due to differences in teamwork time zones. Emerging leadership in virtual teams is dominated by the level of maturity of the members, the environments created to enable them, and their professional experience. They should be given the opportunity to develop their skills and lead, to take on more responsibilities.

Based on the model (Fig. 1), in virtual project teams, motivational and emotional processes could be managed through training that can be conducted formally according to the needs of the team members or at the individual member's discretion. Informally, a team can learn internally among its members, share experience from formal training, or teach each other how to perform certain tasks. It is also important to manage conflict situations that arise between team members. Problems and conflicts can be resolved by managers according to the situation, either openly in the team or individually. Rules and existing policies within companies should be used to foster a safe climate, reduce the occurrence of problems, and thus contribute to the management of motivational and emotional processes. Managers can maintain coherence in teams by focusing on each team member, motivating them with individual conversations and praise.

All teamwork is associated with trust, without which the team would not be able to function, so when managing virtual project teams in international companies, and considering the peculiarities of their team management, the management and the management tools used must be influenced by trust. Confidence affects teamwork and productivity, and helps prevent potential problems arising in managing virtual project teams. 
Aistė Kukytè, Edmundas Jasinskas

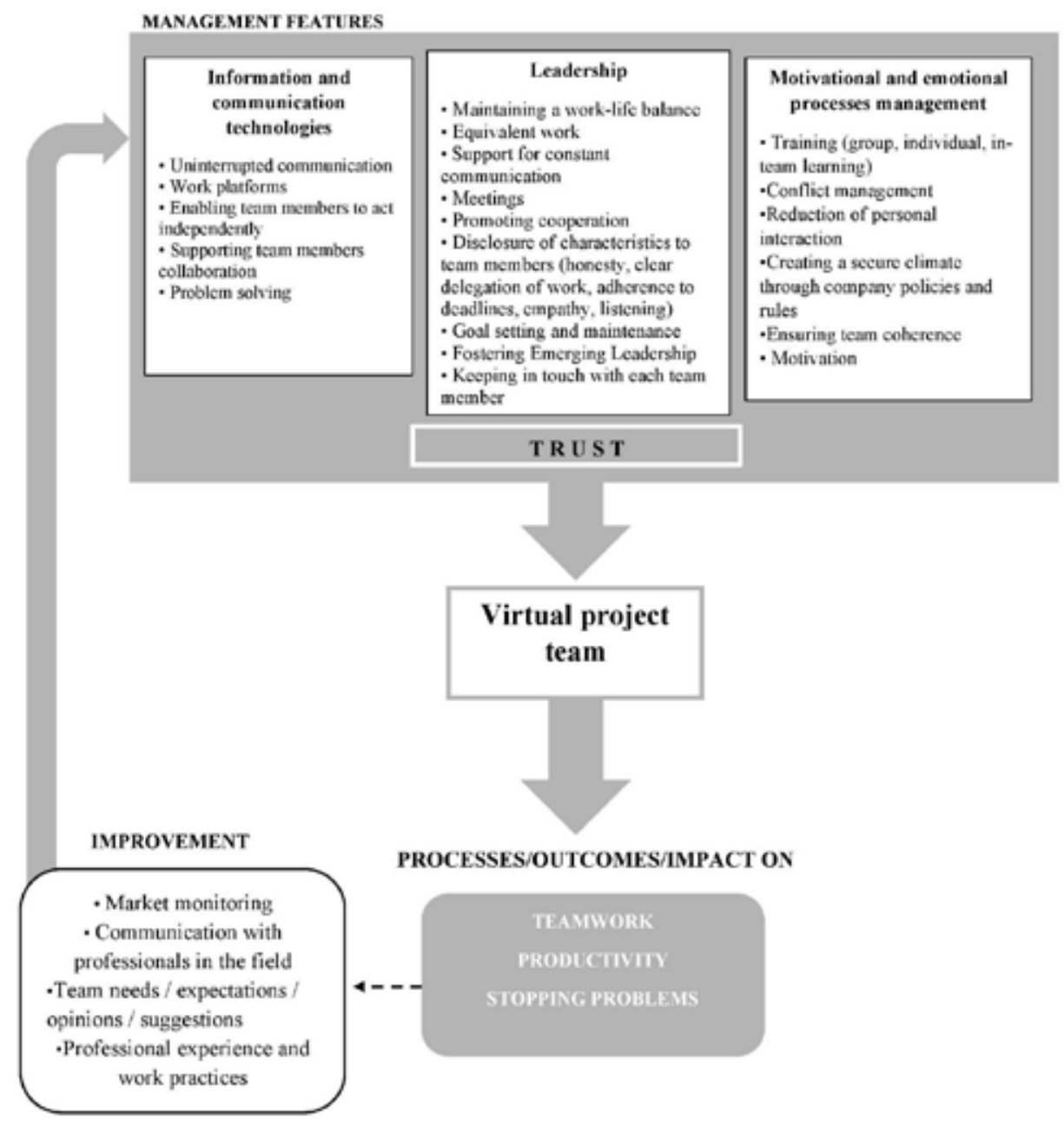

Figure 1. Virtual project team management model in an international company Source: created by the authors based on the results of the study conducted

If the virtual project team is not working properly, the management tools can be improved. The process of improvement can take place by observing the market, and communicating with professionals in the field. The team itself can encourage the improvement of the methods used by the manager by changing their goals, and expressing opinions and suggestions. It should be noted that improvements in team management can be implemented based on professional experience and work practices. 


\section{Discussion}

It is important to discuss the research results, to understand what significance the study brings to an understanding about managing a virtual project team in an international company. The results of the research of the authors Alsharo et al. (2017) revealed that trust strengthens the efficiency of a virtual team, and it is the sharing of knowledge that is important not only at the technological level but also at the social level. The results of the study conducted in this paper also showed that trust helps the team to achieve results that depend on the level of trust. However, the results of the study did not reveal that trust at the technological level is important for a virtual project team leader. Other authors such as Zakaria and Yusof (2018) found that trust is positively affected using the lightness of an existing system, thus creating a culture that reduces geographical distance and influences the behaviour of culturally coordinated teams. The results of the research in the paper could be equated with the results obtained by the authors mentioned, because it was revealed that it is the presence of trust that can help prevent conflicts and reduce the occurrence of problems. Analysing the research results of the impact of information technology on virtual teams, Laitinen and Valo (2018) stated that members of virtual teams attach a lot of importance to information and communication technology: it is considered a work tool, a cause of uncertainty, advantages, challenges, the object of competence, the technical characteristics of the subject, the subject of orientation, the way of expressing closeness, and the common space. The data processed by the informants in this paper also reveals similar aspects, such as that technological advances help more effective management to take effect in virtual teams not only at the team level but also personally, by enabling members to act more independently, not only cooperation between members, but also a quick solution to any problems that arise.

A study by Panteli et al. (2019) revealed that virtual team leaders can actively promote work through the efficient use of resources and relevant practices that promote its development. They can also support and encourage work at all stages of a virtual team's project life cycle. Due to the dispersion of members and the mediation of technology communication, the development of tasks should be a continuous effort that should be visible and supported at various stages. This is confirmed by the results of the research conducted in this paper, which shows that team leaders seek to maintain honesty with team members, adherence to deadlines, the dissemination of motivation, and empowerment of emerging leadership. Managers try to follow the company's policy and established rules by setting clear goals and rules for team members. In terms of leadership in a virtual team, as the results of the study by the authors Guinaliu and Jordán (2016) have shown, the degree of 
attractiveness of leaders influences the trust they create. The results of the research study conducted for this paper do not confirm this statement, as the research was conducted from the position of a virtual project team leader. However, it is important to mention that the results of the research conducted for the paper reveal the qualities of leaders, such as empathy, listening to ideas, help and support. The results of the study reveal aspects of managing the motivational and emotional processes of a virtual team, such as enabling training, motivating team members, managing conflict, ensuring teamwork, and creating a safe climate through company policies and rules.

The results of the research conducted in leadership, compared to the analysis of scientific literature, also reveal the importance of maintaining a personal life and work balance, ensuring equal work, meetings, the disclosure of qualities to team members, and maintaining personal contact with team members. Regarding the management of motivational and emotional processes, a comparison of an analysis of the literature with the results of the research in this paper also reveal that when training is carried out in teams in groups, employees are constantly motivated. When training takes place individually within the team, personal interaction is reduced in the team. The results of the research also reveal that managers improve management tools if necessary, by using market monitoring, communicating with professionals in the field, professional experience and work practice; or by taking note of the team's needs, expectations, opinions and suggestions.

\section{Conclusions}

A qualitative study revealed that the management tools used by virtual project team leaders in international companies are related to information and communication technologies, leadership, and the management of motivational and emotional processes. All these tools try to take account of the specifics of virtual project teams, as the results of the study show that the management of these teams is different from traditional teams in the team's effective operation.

The research results allow us to formulate a virtual project team management model in an international company that reveals the peculiarities of virtual project team management in international companies. The model is useful for companies that seek to properly manage virtual project teams, as well as for productive teamwork.

The results of the research provide a clearer understanding of the tools used in managing virtual project teams, and reveal important international practices. The research results and the model formulated show that team management must be based on trust, which affects teamwork and team productivity, and helps to avoid 
potential problems. The research also reveals how management methods can be improved in virtual project teams as needed. It is recommended to apply the model presented in the paper to managers, because by using the model, managers can change the management tools they apply accordingly, in order to successfully manage virtual project teams.

\section{References}

Alsharo, M., Gregg, D., Ramirezz, R. (2017). Virtual team effectiveness: The role of knowledge sharing and trust. Information \& Management, Vol. 54(4) p. 479-490.

Browne, W., Dreitlein, S., Ha, M., Manzoni, J., Mere, A. (2016). Two Key Success Factors for Global Project Team Leadership: Communications and Human Resource Management. Journal of IT and Economic Development, Vol. 7(2), p. 40-48.

Bhat, S. K., Pande, N., Ahuja, V. (2017). Virtual Team Effectiveness: An Empirical Study Using SEM. Procedia Computer Science, Vol. 122, p. 33-41.

Duran, V., Popescu, A. (2014). The Challenge of Multicultural Communication in Virtual Teams. Procedia Social and Behavioral Sciences, Vol. 109, p. 365-369.

Eubanks, L. D., Palanski, M., Olabisi, J., Joinson, A., Dove, J. (2016). Team dynamics in virtual, partially distributed teams: Optimal role fulfillment. Computers in Human Behavior, Vol. 61, p. 556-568.

Gibbs, L. J., Sivunen, A., Boyraz, M. (2017). Investigating the impacts of team type and design on virtual team processes. Human Resource Management Review, Vol. 27(4), p. 590-603.

Guinalíu, M., Jordán, P. (2016). Building trust in the leader of virtual work teams. Spanish Journal of MarketingESIC, Vol. 20(1), p. 58-70.

Hertel, G., Geister, S., Kondradt, U. (2005). Managing virtual teams: A review of current empirical research. Human Resource Management Review, Vol. 15(1), p. 69-95.

Laitinen, K., Valo, M. (2018). Meanings of communication technology in virtual team meetings: Framing technology-related interaction. International Journal of Human-Computer Studies, Vol. 111, p. 12-22.

Maloney, M. M., Zellmer-Burhn, M. (2006). Building bridges, windows, and cultures: Mediating mechanisms between team heterogeneity and performance in global teams. Management International Review, Vol. 46, p. 697-720.

Mukherjee, D., Natrajan, S. N. (2017). Comparative Analysis of Social Media Tool Used in Software Projects Deploying Virtual Teams. Vision: The Journal of Business Perspective, Vol. 21(4), p. 397-409.

Panteli, N., Yalabik, Y. Z., Rapti, A. (2019). Fostering work engagement in geographically-dispersed and asynchronous virtual teams. Information Technology \& People, Vol. 32(1), p. 2-17.

Wadsworth, B. M, Blanchard, L. A. (2015). Influence tactics in virtual teams. Computers in Human Behavior, Vol. 44, p. 386-393.

Zakaria, N., Yusof, A. M. (2018). Crossing Cultural Boundaries Using the Internet: Toward Building a Model of Swift Trust Formation in Global Virtual Teams. Journal of International Management.

Zuofa, T., Ochieng, G. E. (2017). Working separately but together: appraising virtual project team challenges. Team Performance Management, Vol. 23(5/6), p. 227-242.

Edmundas Jasinskas - Professor, Doctor of Social Sciences ( Economics ), Institute of Social Sciences and Applied Informatics, Vilnius University.

E-mail: edmundas.jasinskas@knf.vu.lt 